\title{
ENZYMEHISTOGHEMICAL ANALYSIS OF 5'-NUCLEOTIDASE POSITIVE MONONUCLEAR CELLS IN LYMPHOCYTIC SUBMANDIBULITIS IN NOD MICE
}

\author{
TAKahide SUGIHARA ${ }^{1}$, YASURo YOSHIMURA ${ }^{1}$, \\ AND OsAMU TANAKA ${ }^{2}$ \\ Department of Oral and Maxillofacial Surgery ${ }^{1}$ and Department of Anatomy ${ }^{2}$, \\ Shimane Medical University, Enya-cho 89-1, Izumo 693
}

Received for publication August 29, 1987 and in revised form November 15, 1987

\begin{abstract}
The localization of $5^{\prime}$-nucleotidase ( $5^{\prime} \mathrm{NT}$ ) activity on mononuclear cells in the inflammatory focus of the submandibular gland of the adult female non-obese diabetic (NOD) mouse was investigated by an enzymehistochemical technique.

At the light microscopical level, the majority of infiltrating mononuclear cells demonstrated intense reaction products on the surface and the reactive cells showed a tendency of forming groups at the center of the inflammatory focus.

At the electron microscopical level, mononuclear cells of the NOD mouse could be roughly differentiated into two kinds of cells, those which demonstrated intense reaction products on the plasma membrane ( $5^{\prime} \mathrm{NT}$ positive) and those which demonstrated less or no reaction products ( 5 'NT negative). In the acini or granular convoluted tuble (GCT) cells, which lie adjacent to the inflammatory focus, $5^{\prime}$ NT positive mononuclear cells were observed and the morphological appearance of these mononuclear cells resembled lymphocytes.

In the present study, the possible role and biological significance of $5^{\prime} \mathrm{NT}$ positive mononuclear cells in the inflammatory focus are discussed.
\end{abstract}

It is well known that, in NOD mice, lymphoproliferative lesions develop spontaneously and frequently in the $\beta$-cells of the Langerhans' islet $(7,10,21)$. In addition, a similar lymphoproliferative lesion also develops in several other organs such as the submandibular gland, lacrimal gland, thyroid gland, adrenal gland and testis (1), and an autoimmune process has been suggested as the pathogenesis of this lesion $(1,14)$.

It has been suggested, on the other hand, that the enzyme $5^{\prime} \mathrm{NT}\left(5^{\prime}\right.$ ribonucleotide phosphohydrolase, EC. 3. 1. 3.5) can be used as a plasma membrane marker for lymphocytes $(13,24,25)$, and this enzyme is thought to be a maturation marker linked to $\mathrm{T}$ and $\mathrm{B}$ cell ontogeny $(3,6,9)$. In addition to the maturity-related differences, this enzyme activity is supposed to be different among $\mathrm{T}$ cell subpopulations $(5,11,22)$, and this enzyme is considered to play an important role in the regulation of the immune system.

We are currently pursuing the mechanisms of acinar cell destruction of salivary glands in patients with Sjögren's syndrome (SS). A recent study (14) suggests that the lesion of the submandibular gland of NOD mice closely resembles that of the salivary gland in patients with SS and we have also obtained a similar result. For the above cited reasons, we have studied the localization of 5'NT activity on mononuclear 
cells in the inflammatory focus of the submandibular gland of the NOD mouse and herein discuss the possible role, significance and/or function of $5^{\prime} \mathrm{NT}$ on mononuclear cells.

\section{MATERIALS AND METHODS}

Fifteen female NOD mice of 19-37 weeks of age, 26-32 $\mathrm{g}$ weight, were studied. The practical procedures of this experiment were as follows; All mice were anesthetized with pentobarbital sodium given intraperitoneally. Vascular perfusion through the left ventricle was begun with physiological saline solution for $1 \mathrm{~min}$, and followed by fixative solution of $0.1 \mathrm{M}$ cacodylate-buffered $2 \%$ paraformaldehyde, $\mathrm{pH}$ 7.2-7.4. After perfusion for $5 \mathrm{~min}$, the submandibular glands were immediately removed. In addition, submandibular lymphnodes were also removed to study the distribution of $5^{\prime} \mathrm{NT}$ activity on lymphocytes.

Preparation of tissues for enzymehistochemistry

The removed glands were immediately immersed in $0.5 \%$ glutaraldehyde, $2 \%$

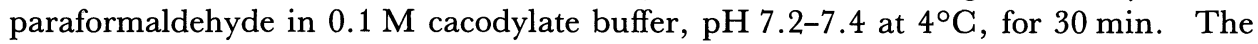
fixed tissues were rinsed with the rinse solution ( $0.1 \mathrm{M}$ cacodylate buffer solution) at $4^{\circ} \mathrm{C}$ for $1 \mathrm{hr}$, and the materials were sliced with a Microslicer (Dosaka EM, Kyoto Japan) at about $40 \mu \mathrm{m}$ thickness. For light microscopical study some of the materials were embedded in OCT compound, and the frozen block was cut into sections 10$30 \mu \mathrm{m}$ in thickness in a cryostat at $-20^{\circ} \mathrm{C}$.

The sliced sections were then incubated in the standard medium for $5^{\prime} \mathrm{NT}$ activity with lead as the capture agent (24); the medium contained $0.1 \mathrm{M}$ Tris-maleate buffer, pH 7.2, $1.4 \mathrm{mM}$ adenosine $5^{\prime}$-monophosphate (AMP, sodium salt, Sigma Chemical Co.), $10 \mathrm{mM} \mathrm{MgSO}_{4}, 1.8 \mathrm{mM} \mathrm{Pb}\left(\mathrm{NO}_{3}\right)_{2}$ and $5 \%$ sucrose or, with cerium as the capture agent (18); the medium contained, 0.1 M Tris-maleate buffer, pH 7.4, $1 \mathrm{mM} \mathrm{AMP} \mathrm{(Sigma} \mathrm{Chemical}$ Co.), $2 \mathrm{mM} \mathrm{CeCl}_{2}, 2 \mathrm{mM} \mathrm{MgCl}_{2}$ and $5 \%$ sucrose. The lead-based method was mainly applied to detect the light microscopical localization of $5^{\prime} \mathrm{NT}$ and the cerium-based method was applied to detect the ultrastructural localization of $5^{\prime} \mathrm{NT}$.

As a control experiment at the light microscopical level, the reaction medium was altered as follows: 1) substrate (AMP) was omitted. 2) betaglycerophosphate was used as a substrate. 3) $\alpha, \beta$-methylen adenosine $5^{\prime}$-diphosphate (AOPCP; Sigma), which is an ADP analogue and potent inhibitor of $5^{\prime} \mathrm{NT}$ activity (12) was added to the final concentration of $1 \mathrm{mM}$.

For the enzymehistochemistry at the light microscope level, the sliced sections, incubated in the lead containing medium (23) for $30 \mathrm{~min}$ at $37^{\circ} \mathrm{C}$, were briefly rinsed with double distilled water and immersed in $1 \%$ ammonium sulfide solution for $1 \mathrm{~min}$, and then mounted in glycerin-jelly.

For the enzymehistochemistry at the electronmicroscope level, the sections, incubated in the medium for $30 \mathrm{~min}$ at $37^{\circ} \mathrm{C}$, were postfixed for $15 \mathrm{~min}$ at $4^{\circ} \mathrm{C}$ with $1 \%$

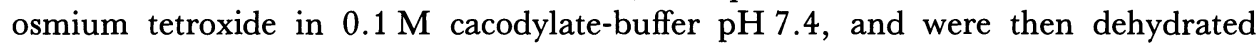
through a graded series of ethanol and treated with propylene oxide and embedded in Spurr's resin. Ultrathin sections cut on a MT-5000 ultramicrotome were stained with $4 \%$ uranyl acetate only or doubly stained with uranyl acetate and lead nitrate and examined under a Hitachi HS-9 or a JEM 1200-EX electron microscope. 


\section{RESULTS}

\section{Enzymehistochemical findings in the submandibular lymphnode}

At the light microscopical level, reactive cells showed a tendency to form groups (Fig. 1a) and a positive staining was demonstrated by a dark ring around the cell surface (Fig. 1a, inset). At the electron microscopical level, roughly two types of lymphocytes were observed, one of which demonstrated dense reaction products on the entire circumference and the other demonstrated little or no reaction products (Fig. 1b). No apparent ultrastructural difference could be found between cells which showed intense $5^{\prime} \mathrm{NT}$ reaction products on the surface and cells which showed less or no reaction products. A part of the plasma membrane of mononuclear cells apposed to $5^{\prime} \mathrm{NT}$ positive cell also showed reaction products (Fig. 1b).

Enzymehistochemical findings in the intact submandibular gland

In the intact salivary glands which are located far from the lymphoproliferative focus, intense reaction products for $5^{\prime} \mathrm{NT}$ were usually located on the plasma membrane of myoepithelial cells apposed to the epithelial cells of acini, ducts and GCT cells (Fig. 2a). The lumial membrane of acinar and ductal cells were also sites of enzymatic activity (Figs. 2a, b). The basolateral plasma membrane of acinar or GCT cells showed minute or little precipitation, while the intercalated ductal cells often demonstrated reaction products on both the lateral and luminal plasma membranes (Fig. 2b).

No reaction products were found in the intracytoplasmic structure. Enzymehistochemical findings in the inflammatory focus of the submandibular gland.

At the light microscopical level, 5'NT positive cells were predominant among infiltrating cells and dense clusters of $5^{\prime} \mathrm{NT}$ positive cells appeared mainly in the center of the infiltrate (Fig. 3a). No reaction products resulting from control experiments (Figs. 3b-d) were observed, at least at the light microscopical level.

At the electronmicroscopical level, the infiltrating mononulcear cells could be roughly differentiated between cells of high membrane $5^{\prime} \mathrm{NT}$ activity and cells of lesser or no enzyme activity (Fig. 4). The acini, GCT cells which lie close to the lesion were usually involuted and reduced in size and the $5^{\prime} \mathrm{NT}$ positive mononuclear cells were frequently observed in the interepithelial space of the acinar or GCT cells (Figs. 5a-c, 6). These interepithelial 5'NT positive mononuclear cells were usually seen to be located in basal regions of the acini and GCT cells, with irregular cell-outlines, 4$12 \mu \mathrm{m}$ in apico-basal diameter, and some of them sent projections into acinar cells (Fig. 5a). Intracellular organelles were poorly developed in these interepithelial 5'NT positive mononuclear cells. The interepithelial $5^{\prime} \mathrm{NT}$ positive mononuclear cells usually showed intense reaction products on the entire cell surface, and they could be easily differentiated from other less stained cells (Fig. 6). Reaction product seen on 5'NT positive cells stained nearby plasma membrane by diffusion artifact (Fig. 6).

The cerium-based enzymehistochemical method usually gave better results when investigating ultrastructural localization of $5^{\prime} \mathrm{NT}$ activity in comparison to the leadbased method, i.e., there was a fine and uniform reaction product and decreased amounts of nonspecific adsorption (Figs. 7a, b). 

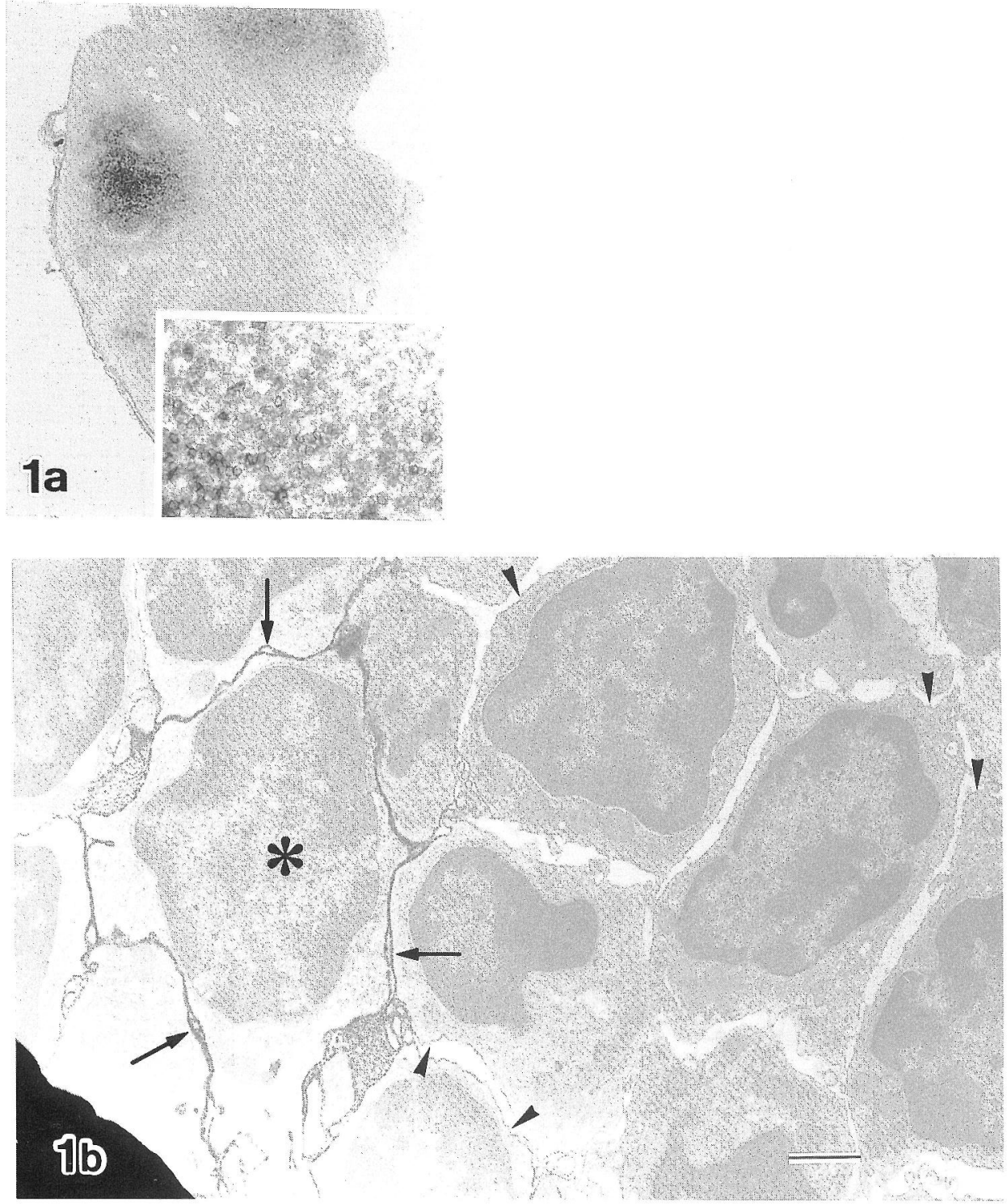

FIGs. 1a, b. The localization of 5'NT activity in the submandibular lymphnode.

1a. 5'NT positive cells show a tendency to form groups. $\times 60$ Inset shows higher magnification. A positively stained cell is shown by a black ring around the cell membrane. $\quad \times 200$

1b. 5'NT positive lymphocytes $\left({ }^{*}\right)$ which show intense reaction products on the entire circumference and negative lymphocytes which show less or no reaction product (arrow heads) are seen. $\times 9,200 \mathrm{Bar}=1 \mu \mathrm{m}$. In this and subsequent figures the reaction product, osmium black, appears along the entire circumference of a reactive cell and stains nearby membrane surfaces by diffusion artifact (arrows). Unless otherwise noted, this and the following electronmicroscopical figures are obtained by the cerium-based method. 


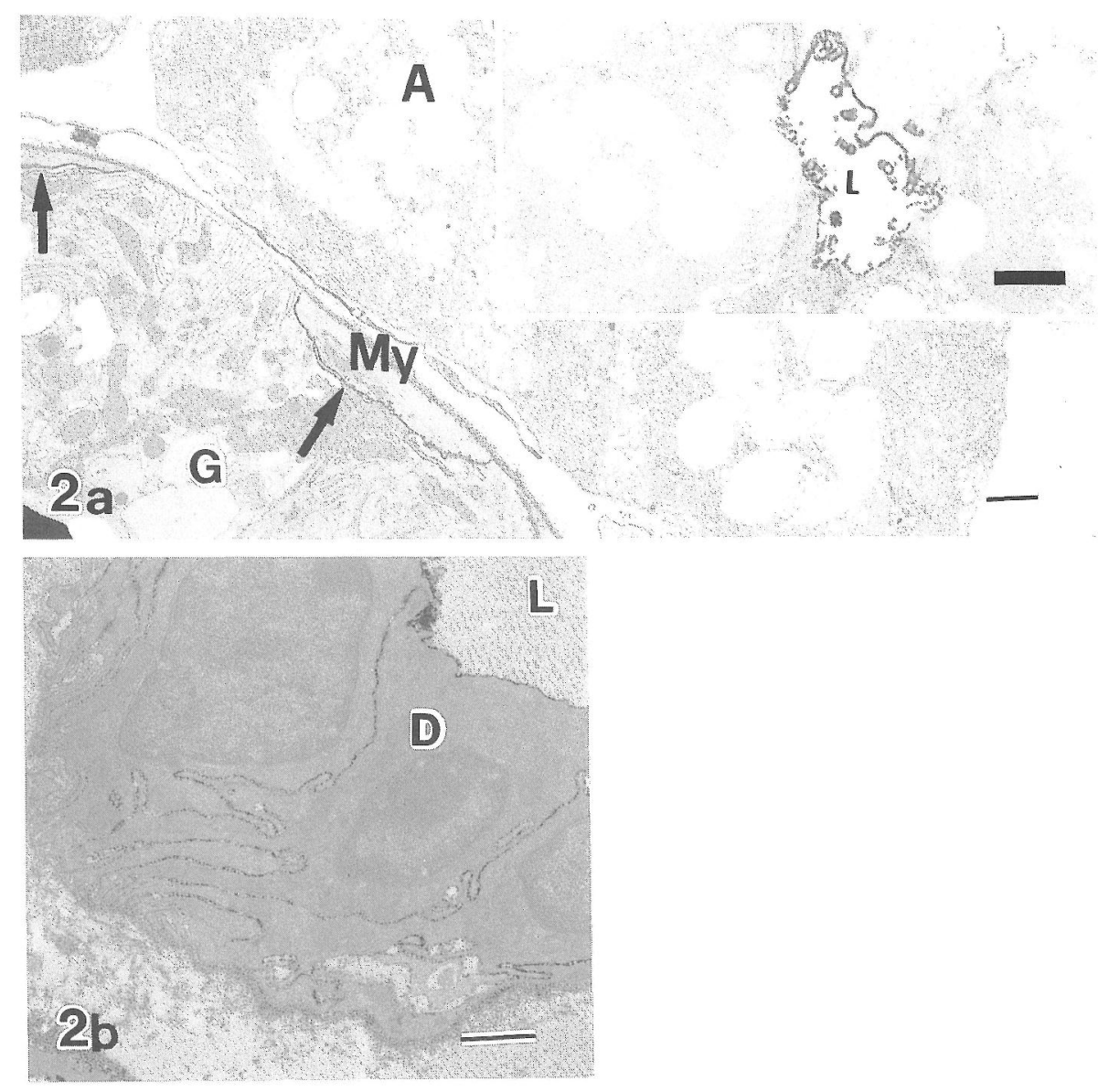

Figs. 2a, b. 5'NT activity in the intact submandibular gland.

2a. 5'NT activity is observed on adjacent plasma membrane (arrow) of myoepithelial (My) and GCT cell (G), whereas the basolateral plasma membrane of the acinar (A) and GCT cells show less or no reaction product of $5^{\prime} \mathrm{NT} . \quad \times 5,600 \quad \mathrm{Bar}=1 \mu \mathrm{m}$. The luminal $(\mathbb{L})$ membrane of acinar cells sometimes show intense reaction (inset). $\times 7,900 \mathrm{Bar}=1 \mu \mathrm{m}$.

2b. Intercalated ductal cells demonstrate reaction products on the lateral and luminal $(\mathrm{L})$ plasma membrane. $\times 8,300$ Bar $=1 \mu \mathrm{m}$.

\section{DISCUSSION}

The enzyme 5'NT catalyzes the hydrolysis of $5^{\prime}$-nucleotides to the corresponding nucleosides. Although this enzyme is associated with the plasma membrane of many cell types $(4,8,13,15,20)$, the role and/or biological significance of $5^{\prime} \mathrm{NT}$ has not been elucidated. However, in human lymphocyte, several lines of evidence suggest that 5 'NT plays an important role in the development of the immune system $(3,9,23)$.

In the lymph node, $5^{\prime} \mathrm{NT}$ positive cells showed a tendency of forming groups. In this study we could not determine the anatomic area of the $5^{\prime} \mathrm{NT}$ positive cell-clustered 
region; however previous study in the rat lymph node (2) indicates that $\mathrm{T}$ cell (paracortex) areas are abundant with $5^{\prime} \mathrm{NT}$ positive cells, although in the human lymph node, $5^{\prime} \mathrm{NT}$ positive staining is observed mainly on the B cell areas (16). Whether this discrepancy can be attributed to the difference in incubation media, the different methods used to identify $\mathrm{T}$ and $\mathrm{B}$ cell areas or the differences in distribution of this enzyme in each species, remains to be determined. However these observations of 5' NT in the lymphatic tissues heighten interest concerning whether or not $5^{\prime} \mathrm{NT}$ is related to a specific subset or a certain function of lymphocytes.

In the present study it has been demonstrated that the light microscopical distribution pattern of $5^{\prime} \mathrm{NT}$ positive cells in the "submandibulitis" is similar to that of Thy $1.2^{+}$(pan T) cells (14) in the following respect; Both $5^{\prime} \mathrm{NT}$ positive and Thy $1.2^{+}$cells are predominant among infiltrating cells, and they are located mainly in the center of the inflammatory focus. This finding suggests that the infiltrating $5^{\prime} \mathrm{NT}$ positive lymphocytes in "lymphocytic submandibulitis" may be predominantly $\mathrm{T}$ cells.

In cytochemical studies for $5^{\prime} \mathrm{NT}$, lead and cerium are generally used as the capture agent. Compared with the lead-based method and the cerium-based method, Robinson and Karnovsky (18) suggest that the cerium-based method gives better results for ultrastructural localization of $5^{\prime} \mathrm{NT}$ than the conventional lead-based method, and we have also obtained a similar result. Although the cerium-based method is useful to study the ultracytochemical localization, this method has a fundamental drawback in that the reaction products at the electron microscopical level are not visible under the light microscope (19). Recent study (17) indicates that cerium can be applied to light microscopical observation. However we have not yet gotten a successful result. For this reason, we used the lead-based method to detect the light microscopical localization of $5^{\prime} \mathrm{NT}$ and the cerium-based method to detect the ultrastructural localization of $5^{\prime} \mathrm{NT}$ respectively, although the question remains

FIGs. 3a-d. The localization of 5'NT activity in the inflammatory focus of the submandibular gland of the NOD mouse.

3a. Dense clusters of 5'NT positive cells appear mainly in the center of the infiltrate. $\quad \times 100$

$3 \mathrm{~b}-\mathrm{d}$. Control experiments demonstrate no reaction products on the infiltrating mononuclear cells, at least at the light microscopical level.

3b. AMP is omitted. $\times 100$

3c. $\beta$-glycerophosphate is substituted for AMP. $\times 150$

3d. $1 \mathrm{mM}$ AOPCP is added to the complete medium. $\times 100$

Fig. 4. Ultracytochemical localization of $5^{\prime} \mathrm{NT}$ activity on infiltrating mononuclear cells. Infiltrating lymphocytes partly express high $5^{\prime} \mathrm{NT}$ activity $\left({ }^{*}\right)$ and partly express little or no activity.

A part of plasma membrane of mononuclear cells apposed to $5^{\prime} \mathrm{NT}$ positive cells also show reaction products (arrow heads) which are supposed to be a diffusion artifact. $\times 7,500 \mathrm{Bar}=1 \mu \mathrm{m}$.

FIGs. 5a-c. 5'NT positive mononuclear cell $\left({ }^{*}\right)$ in the acinus (A) or GCT(G) cells.

5a. $\quad 5^{\prime} \mathrm{NT}$ positive cell $\left({ }^{*}\right)$ is seen in the acinus (A). Its surface is irregular and has a pseudopodialike protrusion (arrow). $\quad \times 4,000 \mathrm{Bar}=2 \mu \mathrm{m}$. St: striated duct.

5b. Although the luminal plasma membrane of the acinar cell (A) demonstrates reaction product (arrow), staining density is apparently less in comparison to that seen on the surface of mononuclear cell $\left(^{*}\right) . \quad \times 10,000 \mathrm{Bar}=1 \mu \mathrm{m}$.

5c. The density of reaction product seen on the mononuclear cell $\left({ }^{*}\right)$ is apparently strong in comparison to that seen on the myoepithelial cell plasma membrane (arrow) or adjacent plasma membrane of GCT cells (arrow heads). $\quad \times 6,500 \mathrm{Bar}=1 \mu \mathrm{m} . \quad \mathrm{My}$ : myoepithelial cell, G: GCT cell. 

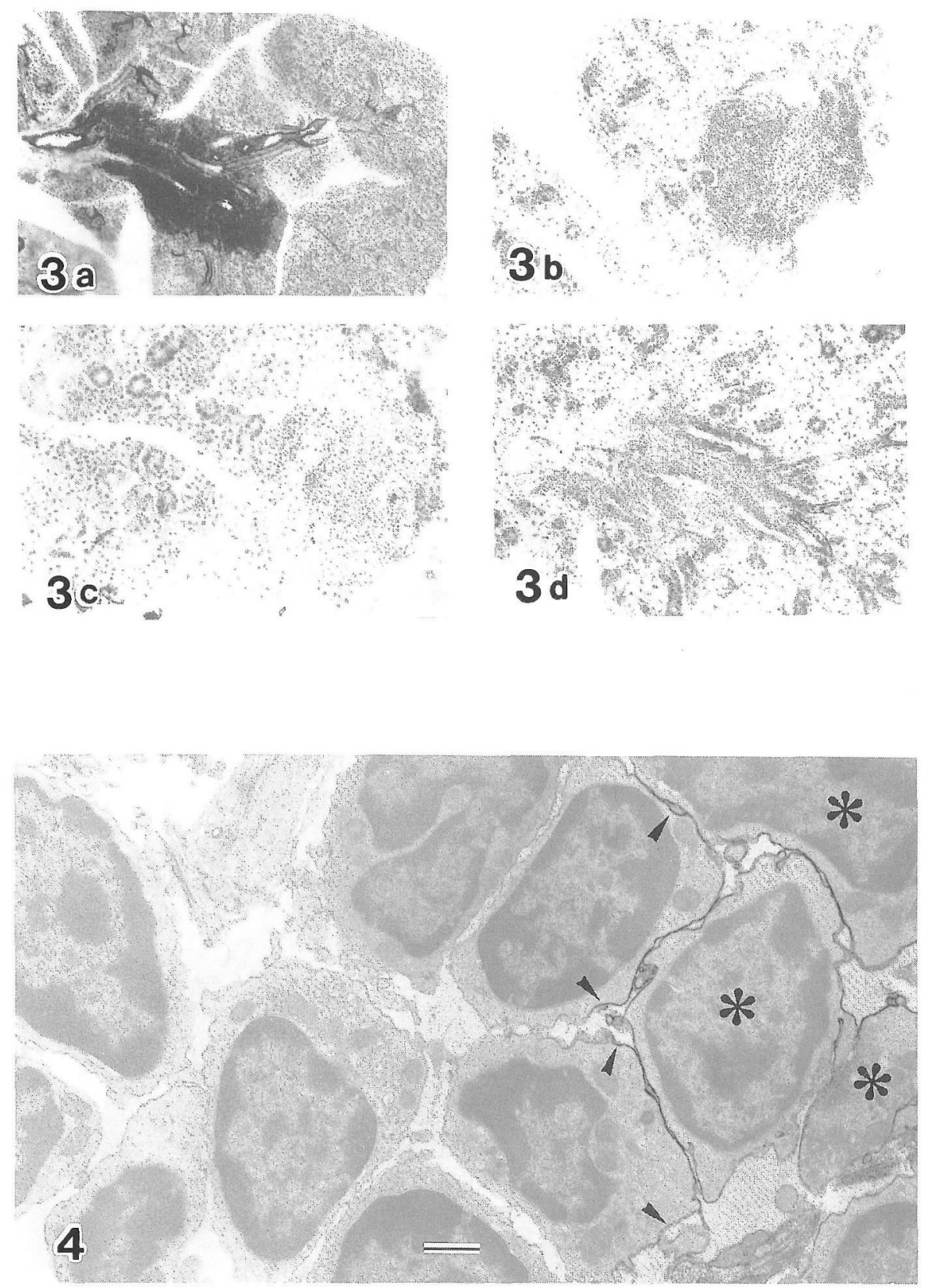

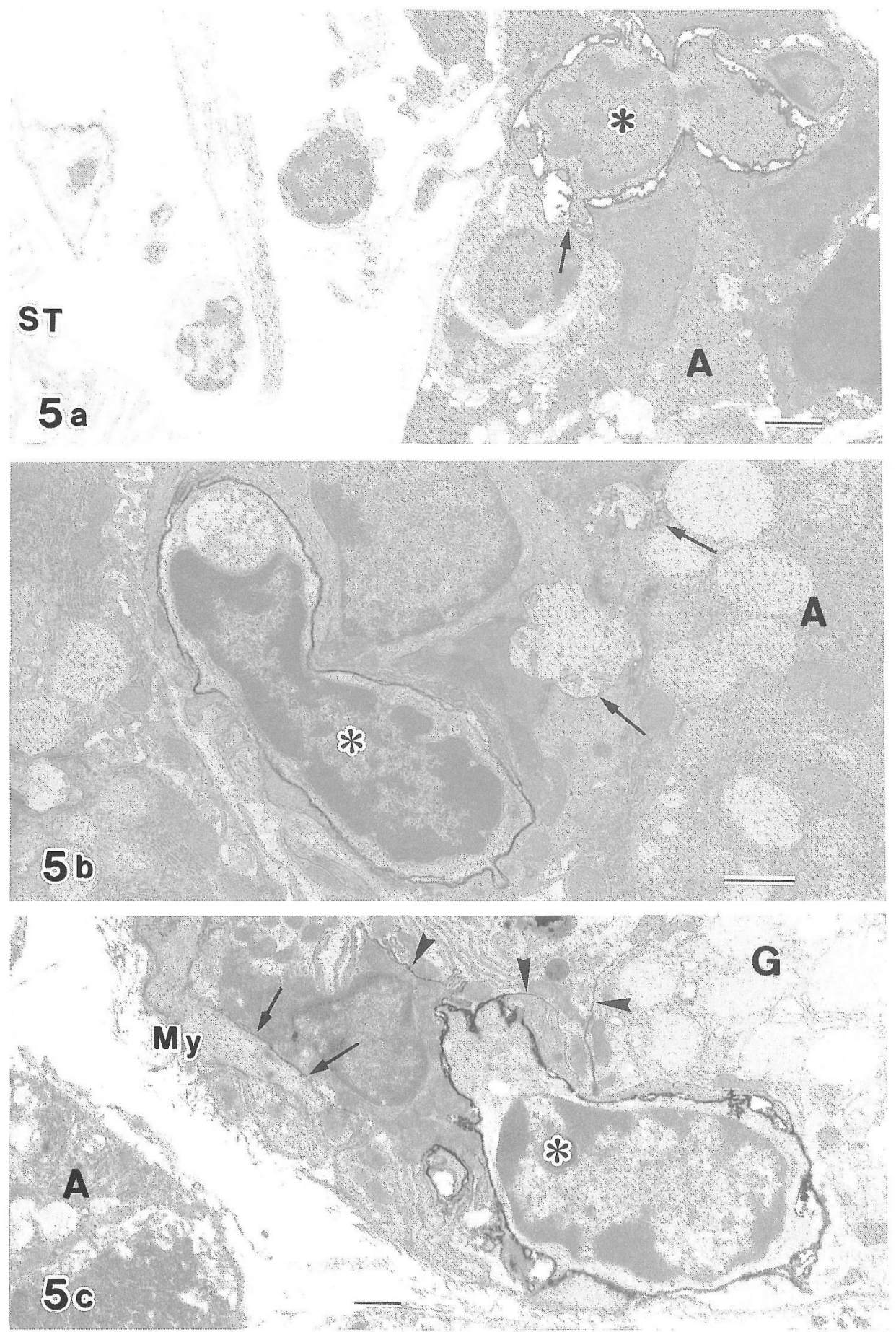


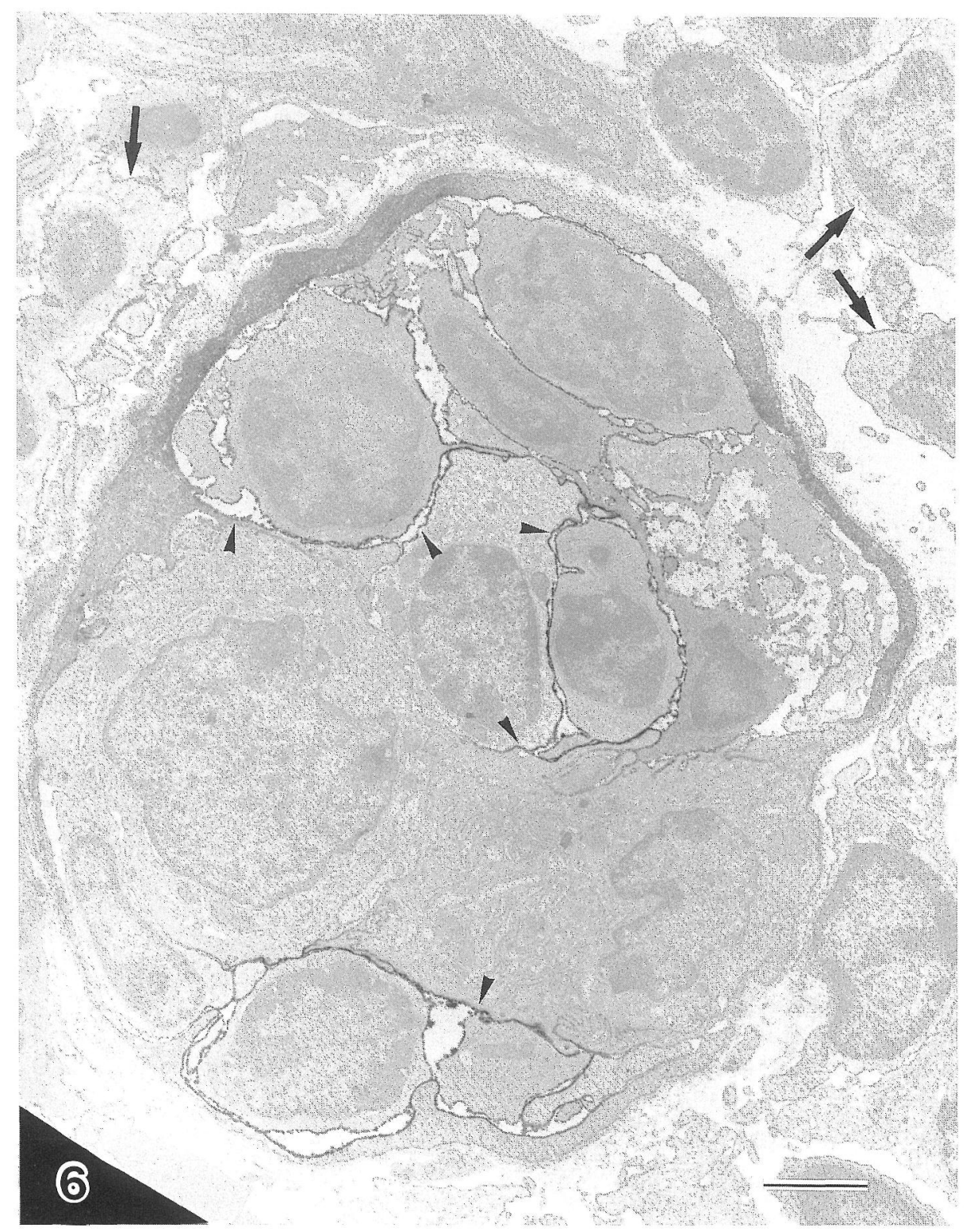

FIG. 6. In the involuted acinus- or duct-like structure, 5'NT positive cells are seen. These 5'NT positive cells can be differentiated from other weakly stained mononuclear cells (arrows). Reaction product seen on $5^{\prime} \mathrm{NT}$ positive cells stains nearby membrane by diffusion artifact (arrow heads). $\times 6,700 \mathrm{Bar}=2 \mu \mathrm{m}$. 

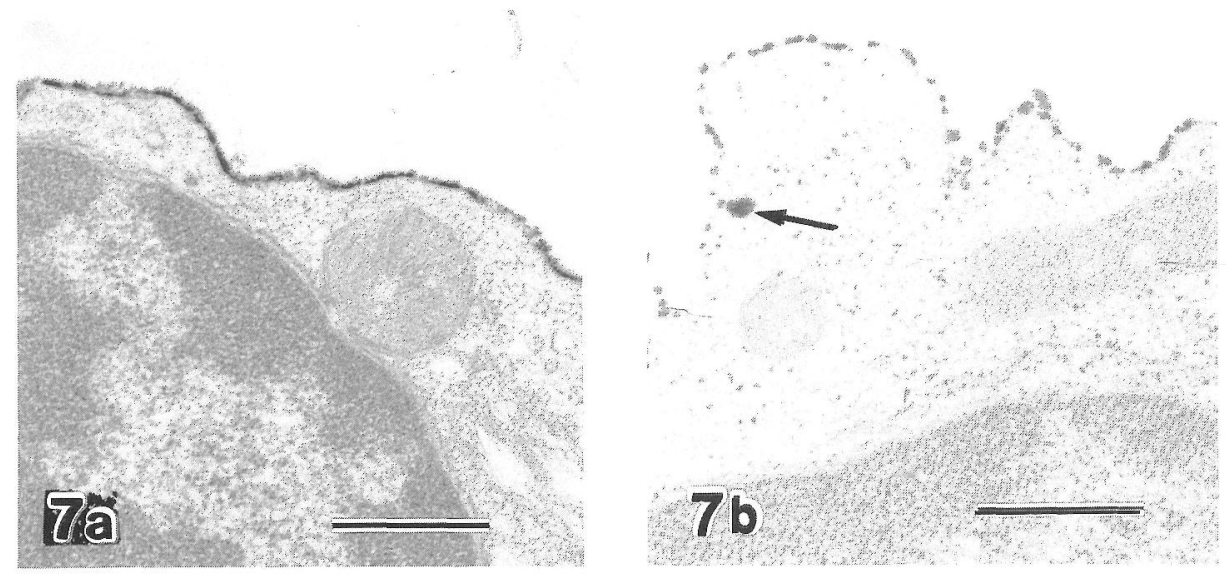

Figs. 7a, b. Comparison of the cerium-based method with the lead-based method.

7a. 5'NT activity on an infiltrating mononuclear cell by the cerium-based method. The reaction product is uniformly distributed. $\times 32,000 \mathrm{Bar}=0.5 \mu \mathrm{m}$.

7b. 5'NT activity on an infiltrating mononuclear cell by the lead-based method. There is a coarse and diffuse reaction product on the surface and nonspecific deposits of reaction product in the cell interior (arrow). $\times 34,000 \mathrm{Bar}=0.5 \mu \mathrm{m}$.

whether the result of cytochemical study based on lead agrees well with that based on cerium.

In this study, we have roughly differentiated the mononuclear cells into two types, i.e., 5'NT positive and negative. However there may be a problem in classifying them into two types, because it seems probable that there may be a cell which belongs to a third type, intermediary between $5^{\prime} \mathrm{NT}$ positive and negative, i.e., those cells which show weak but definite precipitates on the entire circumference. Indeed, it was often difficult to determine whether these cells were $5^{\prime} \mathrm{NT}$ positive or negetive. Dianzani et al. (5) indicate that cytochemical analyses have shown that lymphocyte $5^{\prime} \mathrm{NT}$ expression occurs in an all or nothing fashion, i.e., cells are either $5^{\prime} \mathrm{NT}$ positive or $5^{\prime} \mathrm{NT}$ negative. In light of this report, the possibility cannot be excluded that the reaction products on the cells of third type are nonspecific deposits. However it is conceivable that lymphocyte $5^{\prime} \mathrm{NT}$ expression appears to go stepwide according to the difference of subset and/or function. The previous report (17), that the density of reaction product seen in cerium-based cytochemical preparations reflects the enzyme activity at those sites, may support this concept. To clarify these questions, it may be necessary to compare the results of immunohistochemical study with anti- $5{ }^{\prime} \mathrm{NT}$ antibody with the results of enzymehistochemical study, as has been previously reported by Yamashina et al. (26). Nevertheless, mononuclear cells which were observed in the acini usually showed intense reaction product on the entire circumference, and they could be easily differentiated from other weakly stained cells. So in this study, for convenience we have roughly differentiated mononuclear cells into two types.

At the electron microscopical level, $5^{\prime} \mathrm{NT}$ positive mononulcear cells were also observed in the involuted acini which lie close to the lesion. It is most probable that 
these mononuclear cells in the acini are the invaded lymphocytes in the following respects: First, we have observed that lymphocytes invade the acini (unpublished data) and the morphological appearance of the $5^{\prime} \mathrm{NT}$ positive mononuclear cells resembles that of lymphocyte. Second, no 5'NT positive mononuclear cell could be identified in the intact acinar cells which lie far from the lymphocyte infiltrating focus. Third, it is suggested that matured $\mathrm{T}$ lymphocyte has high $5^{\prime} \mathrm{NT}$ activity. In NOD mice, we have also observed in thymus, that $5^{\prime} \mathrm{NT}$ positive cells are mainly located in the medullary region (unpublished data) where matured $\mathrm{T}$ cells are thought to be abundantly located (9). Fourth, a recent report indicates that, among $\mathrm{T}$ cell subpopulation, $\mathrm{OKT}^{+}$(cytotoxic/suppressor) cells have high enzymatic activity in comparison to $\mathrm{OKT}_{4}^{+}$(helper/inducer) cells $(11,22)$. Furthermore, among OKT8 ${ }^{+}$ cells, cytotoxic cell precursors have high $5^{\prime} \mathrm{NT}$ activity, whereas the suppressor phenotype and function displays less or no $5^{\prime} \mathrm{NT}$ activity (5). It is therefore probable that the invaded lymphocytes exhibit intense $5^{\prime} \mathrm{NT}$ activity, although in regard to the last point, the question remains whether the results of human lymphocyte agree well with those of the mouse lymphocyte.

However the possibility cannot be excluded that $5^{\prime} \mathrm{NT}$ positive mononuclear cells in the acini or GCT cells are not lymphocytes, because $5^{\prime} \mathrm{NT}$ is not a specific marker for lymphocyte. Indeed, this study as well as others (26) has shown that a certain portion of plasma membrane of acinar, ductal and myoepithelial cells also have intense enzymatic activity. It is therefore possible that the reaction product which appears along the myoepithelial or ductal cell plasma membrane may stain nearby mononuclear cell membrane by diffusion artifact and give false-positive results. So we must be careful when interpreting the results of cytochemical localization of 5 'NT activity especially when mononuclear cells are located between duct cells or lie close to myoepithelial cells. In any case, on the basis of our findings alone it is not possible to state whether $5^{\prime} \mathrm{NT}$ positive mononuclear cells present in the acini or GCT cells are lymphocytes or not. In order to make this point clear, there is a need to examine enzymehistochemical localization of $5^{\prime} \mathrm{NT}$ activity on a lymphocyte-target cell model system in vitro. Nevertheless, the present study suggest that further enzymehistochemical study for $5^{\prime} \mathrm{NT}$ on lymphoproliferative lesion may be helpful in clarifying the role and/or significance of $5^{\prime} \mathrm{NT}$ in lymphocyte function.

\section{ACKNOWLEDGEMENTS}

The authors are grateful to Dr. T. Yoshioka for his valuable suggestions and criticism and assistant Prof. S. Suzuki for providing the NOD mice. We thank Mr. Ronald S. Cairns for revision of the manuscript.

\section{REFERENCE}

1. Asamoto H., Akazawa, Y., Tashiro, S., Oishi, M., Azuma, T., Koide, S., Sudo, K., Yokota, H. and Tochino, Y.: Infiltration of lymphocytes in various organs of the NOD (non-obese diabetic) mouse. J. Japan Diab. Soc. (in Japanese) 27; 775-781, 1984.

2. Barton, R. W. and Goldschneider, I.: $5^{\prime}$-nucleotidase activity in subpopulations of rat lymphocytes. J. Immunol. 121; 2329-2334, 1978. 
3. Cohen, A., Lee, J. W. W., Dosch, H-M. and Gelfand, E. W.: The expression of deoxyguanosine toxicity in $\mathrm{T}$ lymphocyes at different stages of maturation. J. Immunol. 125; 15781582, 1980.

4. Depierre, J. W. and Karnovsky, M. L.: Ecto-enzymes of the guinea pig polymorphonuclear leukocyte. I. Evidence for an ecto-adenosine monophosphatase, -adenosine triphosphatase, and -p-nitrophenyl phosphatase. J. Biol. Chem. 249; 7111-7120, 1974.

5. Dianzani, U., Massaia, M., Pileri, A., Grossi, C. E. and Clement, L. T.: Differential expression of ecto- 5 ' nucleotidase activity by functionally and phenotypically distinct subpopulations of human Leu-2 ${ }^{+} / \mathrm{T}^{+}{ }^{+}$lymphocytes. J. Immunol. 137; 484-489, 1986.

6. Edwards, N. L., Gelfand, E. W., Burk, L., Dosch, H-M. and Fox, I. H.: Distribution of 5'nucleotidase in human lymphoid tissues. Proc. Natl. Acad. Sci. (USA) 76; 3474-3476, 1979.

7. Fujita, T., Yui, R., Kusumoto, Y., Serizawa, Y., Makino, S. and Tochino, Y.: Lymphocytic insulitis in a "Non-Obese Diabetic (NOD)" strain of mice: An immunohistochemical and electron microscope investigation. Biomed. Res. 3; 429-443, 1982.

8. Groothuis, G. M. M., Hulstaert, C. E., Kalicharan, D. and Hardonk, M. J.: Plasma membrane specialization and inltracellular polarity of freshly isolated rat hepatocytes. Eur. J. Cell Biol. 26; 43-51, 1981.

9. Ma, D. D. F., Sylwestrowicz, T. A., Granger, S., Massaia, M., Franks, R., Janossy, G. and Hoffbrand, A. V.: Distribution of terminal deoxynucleotidyl transferase and purine degradative and synthetic enzymes in subpopulations of human thymocytes. J. Immunol. 129; 1430-1435, 1982.

10. Makino, S., Kunimoto, K., Muraoka, Y., Mizushima, Y., Katagiri, K. and Tochino, Y.: Breeding of a non-obese, diabetic strain of mice. Exp. Anim. 29; 1-13, 1980.

11. Massaia, M., Ma. D. D. F., Sylwestrowicz, T. A., Tidman, N., Gillprice, Janossy G. and Hoffbrand, A. V.: Enzymes of purine metabolism in human peripheral lymphocyte subpopulations. Clin. Exp. Immunol. 50; 148-154, 1982.

12. Matsubara, S., Tamada, T., Kurahashi, K. and Saito, T.: Ultracytochemical localizations of adenosine nucleotidase activities in the human term placenta, with special reference to $5^{\prime}$ nucleotidase activity. Acta histochem. cytochem. 20; 409-419, 1987.

13. Misra, D. N., Gill, T. J. and Estes, L. W.: Lymphocyte plasma membranes II. Cytochemical localization of 5'-nucleotidase in rat lymphocytes. Biochim. Biophys. Acta 352; 455-461, 1974.

14. Miyagawa, J., Hanafusa, T., Miyazaki, A., Yamada, K., Fujino-Kurihara, H., Nakajima, H., Kono, N., Nonaka, K., Tochino, Y. and Tarui, S.: Ultrastructural and immunocytochemical aspects of lymphocytic submandibulitis in the non-obese diabetic (NOD) mouse. Virchows Arch. [Cell pathol.] 51; 215-225, 1986.

15. Monneron, A.: Ultrastructural study of membrane-bound enzymes in thymocytes. $J$. Histochem. Cytochem. 22; 1128-1134, 1974.

16. Müller-hermelink, H. K.: Characterization of the B-cell and T-cell regions of human lymphatic tissue through enzyme histochemical demonstration of ATPase and 5 '-nucleotidase activities. Virchows Arch. [Cell Pathol.] 16; 371-378, 1974.

17. Okada, T., Kobayashi, T., Hakoi, K. and Seguchi, H.: A simple method for light microscopical visualization of phosphohydrolase activities in materials processed for cerium-based ultracytochemistry. Acta histochem. cytochem. 20; 105-110, 1987.

18. Robinson, J. M. and Karnovsky, M. J.: Ultrastructural localization of $5^{\prime}$-nucleotidase in guinea pig neutrophils based upon the use of cerium as capturing agent. J. Histochem. Cytochem. 31; 1190-1196, 1983.

19. Robinson, J. M. and Karnovsky, M. J.: Ultrastructural localization of several phosphatases with cerium. J. Histochem. Cytochem. 31; 1197-1208, 1983.

20. Rodan, G. A., Bourret, L. A. and Cutler, L. S.: Membrane changes during cartilage maturation. Increase in $5^{\prime}$-nucleotidase and decrease in adenosine inhibition of adenylate cyclase. $J$. Cell Biol. 72; 493-501, 1977.

21. Shimizu, J., Ikehara, S., Toki, J., Ohtsuki, H., Yasumizu, R. and Hamashima, Y.: Immunohistochemical and ultrastructural studies on beta cell destruction in NOD mouse, an animal model for type I diabetes mellitus. Acta histochem. cytochem. 20; 9-19, 1987. 
22. Thompson, L. F., Saxon, A., O'Connor, R. D. and Fox, R. I.: Ecto-5'-nucleotidase activity in human T cell subsets. J. Clin. Invest. 71; 892-899, 1983.

23. Thompson, L. F., Ruedi, J. M., O'Connor, R. D. and Bastian, J. F.: Ecto-5'-nucleotidase expression during human B cell development. An explanation for the heterogeneity in B lymphocyte ecto- $5^{\prime}$-nucleotidase activity in patients with hypogammaglobulinemia. J. Immunol. 137; 2496-2500, 1986.

24. Uusitalo, R.J. and Karnovsky, M.J.: Surface localization of 5 '-nucleotidase on the mouse lymphocyte. J.Histochem. Cytochem. 25; 87-96, 1977.

25. Uusitalo, R. J. and Karnovsky, M. J.: $5^{\prime}$-nucleotidase in different populations of mouse lymphocytes. J. Histochem. Cytochem. 25; 97-103, 1977.

26. Yamashina, S., Katsumata, O., Wada, I. and Kato, K.: Electron microscopic localization of 5 '-nucleotidase in rat salivary glands: Comparative enzyme- and immunohistochemical studies. Histochemistry 84, 231-236, 1986. 